\title{
Characterization of Stevia rebaudiana Bertoni Accessions Cultived in Southern Brazil
}

\author{
Felipe Francisco ${ }^{1}$, Gabriely Pinto Pereira ${ }^{1}$, Marília Pereira Machado ${ }^{1}$, Luiz Alberto Kanis ${ }^{1} \&$ Cícero Deschamps ${ }^{2}$ \\ ${ }^{1}$ Programa de Pós-Graduação em Agronomia Produção Vegetal, Universidade Federal do Paraná, Curitiba, Brazil \\ ${ }^{2}$ Programa de Pós-Graduação em Ciências da Saúde, Universidade do Sul de Santa Catarina, Tubarão, Brazil \\ Correspondence: Cícero Deschamps, Departamento de Fitotecnica e Fitossanitarismo, Universidade Federal do \\ Paraná, Curitiba, Rua dos Funcionários, 1540, Brazil. Tel: 55-(41)-3350-5687. E-mail: cicero@ufpr.br
}

Received: December 6, 2017 Accepted: January 7, 2018 Online Published: February 15, 2018

doi:10.5539/jas.v10n3p353 URL: https://doi.org/10.5539/jas.v10n3p353

\begin{abstract}
Stevia, a native species of South America, is commercially important as a source of the non-caloric diterpene glycosides stevioside and rebaudioside-A. Although it has been cultivated in southern Brazil, the production is not enough to meet the domestic market demand. This study evaluated biomass accumulation, morphological and physiological characters, and steviol glycosides yield of seven stevia accessions after two cuts. A great variation for the different plant characteristics was found between the first and second cuts. There was a positive correlation between biomass production and SGs content and productivity. The overall Principal Components Analysis results in both cuts indicate that the accessions CE7 and CE14 presented great Reb-A yield, height and lodging (\%). The accessions CE4 and CE12 produced high Ste yield and accessions CE6, CE8 and CE9 the highest leaf:stem ratio and low SGs. The stevia accessions showed characteristics of the interest for crop improvement for both biomass and SGs production.
\end{abstract}

Keywords: productivity, rebaudioside-A, stevia, stevioside

\section{Introduction}

The Stevia genus has about 230 species and Stevia rebaudiana, is a herbaceous plant popularly known as stevia with economic importance due the production of steviol diterpene glycosides (SGs) in the leaves, mainly stevioside (Ste) and rebaudioside-A (Reb-A) (Kinghorn, 2002; Mondança et al., 2012; Rieck, 2012). The World demand for stevia has increased in the last years (Industry ARC, 2014). Although the production and consumption of stevia are mostly concentrated in China and Japan, stevia cultivation is expected to increase in many other countries because of its recent approval for consumption by United States and Europe (Rieck, 2012; Saad et al., 2014). In Brazil, stevia cultivation is recommended for different regions, especially for Mato Grosso do Sul and Parana states (Lima Filho et al., 2004). Studies for selection and improvement of adapted genotypes are considered important for stevia cultivation in the country.

The main stevia yield components are leaf dry weight, Ste and Reb-A content and Reb-A:Ste ratio (Ramesh et al., 2006). The Reb-A:Ste ratio is the accepted measure of sweetness quality. If Reb-A is present in equal amount than Ste, the aftertaste is eliminated (Yadav et al., 2011). Consequently, stevia breeding programs have focused on Reb-A content and Reb-A:Ste ratio. In commercial crops of southern Brazil, Reb-A content varied from 0.46 to $12.23 \%$ and Reb-A:Ste ratio varied from 0.03 to 1.59 (Anami et al., 2010). These variations are due the fact that the highest percentage of diterpene glycosides are found in the leaves and it is highly correlated with plant genotype (Giraldo et al., 2005).

Therefore, stevia breeding programs to obtain new cultivars with desirable and stable chemical profiles may improve the quality of raw materials for the industry. The genetic variability of spontaneous populations can be identified and used in breeding programs to increase the production and quality of the steviol glycosides. Therefore, the purpose of the present research was to: (i) evaluate biomass accumulation, morphological characters, physiological indices, and (ii) steviol glycosides yield of seven stevia accessions to assess its breeding potential. 


\section{Method}

\subsection{Experimental Area}

The experiment was carried out under field conditions in Parana state, southern Brazil $\left(25^{\circ} 38^{\prime} 58^{\prime \prime} \mathrm{S}, 49^{\circ} 12^{\prime} 59^{\prime \prime} \mathrm{W}\right.$, altitude $960 \mathrm{~m}$ ). The climate is characterized as humid subtropical with cool summers, frequent frost during the winter and absence of a dry season. The environmental conditions (maximum and minimum temperature, relative humidity, sun radiation, sunshine hours, and rainfall) during the experiments are shown in Table 1.

Table 1. Climatic data of the experimental area (Curitiba, PR, Brazil)

\begin{tabular}{|c|c|c|c|c|c|c|c|}
\hline Month/Year & Min Temp & Max Temp & Mean Temp & Humidity & Rainfall & Sunshine & $\operatorname{Rad}$ \\
\hline & -------------- & -.-- ${ }^{\circ} \mathrm{C}-$ & ---------------- & --- \% --- & --- mm --- & -- hours -- & $--\mathrm{W} \mathrm{m}^{-2}--$ \\
\hline \multicolumn{8}{|c|}{ First growing period } \\
\hline Nov/2013 & 14.2 & 23.7 & 18.0 & 87.1 & 105.6 & 13.3 & 352.0 \\
\hline Dez/2013 & 16.2 & 26.2 & 20.1 & 85.0 & 103.8 & 13.6 & 395.0 \\
\hline $\mathrm{Jan} / 2014$ & 17.4 & 28.7 & 21.8 & 83.1 & 198.6 & 13.4 & 446.0 \\
\hline $\mathrm{Feb} / 2014$ & 17.3 & 28.1 & 21.6 & 83.4 & 135.2 & 12.9 & 397.8 \\
\hline Mean & 16.3 & 26.7 & 20.4 & 84.7 & 135.8 & 13.3 & 397.7 \\
\hline \multicolumn{8}{|c|}{ Second growing period } \\
\hline Mar/2014 & 16.1 & 25.2 & 19.7 & 87.8 & 121.2 & 12.2 & 324.2 \\
\hline $\mathrm{Abr} / 2014$ & 14.5 & 22.6 & 17.6 & 90.5 & 68.4 & 11.4 & 259.2 \\
\hline Mai/2014 & 11.8 & 20.7 & 15.3 & 88.7 & 88.0 & 10.7 & 250.1 \\
\hline Mean & 14.1 & 22.8 & 17.5 & 89.0 & 92.5 & 11.4 & 277.8 \\
\hline
\end{tabular}

Note. Sistema Meteorológico do Paraná (2015).

Soil samples were collected from the experimental area and the results were $\mathrm{pH}=5.2 ; \mathrm{Al}^{+3}=0.0 \mathrm{cmol}_{\mathrm{c}} \mathrm{dm}^{-3}$; $\mathrm{H}^{+}+\mathrm{Al}^{+3}=5.8 \mathrm{cmol}_{\mathrm{c}} \mathrm{dm}^{-3} ; \mathrm{Ca}^{+2}=6.1 \mathrm{cmol}_{\mathrm{c}} \mathrm{dm}^{-3} ; \mathrm{Mg}^{+2}=3.1 \mathrm{cmol}_{\mathrm{c}} \mathrm{dm}^{-3} ; \mathrm{K}^{+}=0.88 \mathrm{cmol}_{\mathrm{c}} \mathrm{dm}^{-3} ; \mathrm{P}=35.4 \mathrm{mg}$ $\mathrm{dm}^{-3} ; \mathrm{C}=26.3 \mathrm{~g} \mathrm{dm}^{-3}$; base saturation $63 \%$ with $400 \mathrm{~g} \mathrm{~kg}^{-1}$ of clay. Soil correction was performed according to the ROLAS (2004) recommendations.

\subsection{Plant Material and Harvesting}

The seven stevia accessions (CE4, CE6, CE7, CE8, CE9, CE12 and CE14) were obtained from Embrapa (Brazilian Agricultural Research Corporation, Center of Genetic Resources, Brazil). The plant material was micropropagated using MS medium (Murashige \& Skoog, 1962) modified with $20 \mathrm{~g} \mathrm{~L}^{-1}$ sucrose and $6 \mathrm{~g} \mathrm{~L}^{-1}$ agar. Growth conditions were 16-hour photoperiod with photon flux density of $20 \mu \mathrm{mol} \mathrm{m}^{-2} \mathrm{~s}^{-1}$ and temperature of $25 \pm 2{ }^{\circ} \mathrm{C}$. The plantlets were transferred and maintained under greenhouse conditions for 14 days with intermittent mist irrigation for 5 seconds each 30 minutes, followed by 20 additional days with irrigation as needed. At the end of this period, plants were selected for field evaluation. Before being transferred to the field, plants were pruned to $20 \mathrm{~cm}$ in height, remaining with three pairs of leaves. The plot size was $1.5 \times 2.5 \mathrm{~m}$ with $0.6 \mathrm{~m}$ border between plots containing 25 plants with spacing of $0.5 \times 0.25 \mathrm{~m}$. The nine plants in the center were used for evaluation.

Plants were first harvested $5 \mathrm{~cm}$ above the base of the stem after 114 days from transplanting date (first cut) and 84 days after the first harvest (second cut), at which time $5 \%$ of the plants presented flowers, according to Lima Filho et al. (2004).

\subsection{Morphological Characters and Biomass Accumulation}

Leaves were separated from the stems and dried at $65^{\circ} \mathrm{C}$ for 48 hours in a hot dry oven for leaf dry weight, stem dry weight and total dry mass determinnation.

Plant height was determined by the distance to the highest point of the plant. The percentage of lodging was assessed by counting the plant branches positioned horizontally during the experiment period (Lima Filho et al., 2004).

The number of secondary branches (NSB) and tertiary branches (NTB) (shoots per plant) was determined from three plants randomly selected from each plot. 


\subsection{Physiological Indices}

From the biometric measurements, the physiological indices were calculated (Equations 1, 2 and 3), which reflect the morphological and physiological conditions of the plant during its ontogenetic cycle, describe by Radford (1967).

Fifty discs of $0.785 \mathrm{~cm}^{2}$ leaves of each experimental plot were weighed to measure the leaf area index (LAI) calculated proportionally to the total leaves mass of the plot.

The leaf area ratio (LAR) expressed the foliar area useful for photosynthesis and was defined as the quotient between a foliar area (FA) and total dry weight (TDW).

$$
L A R=F A / T D W
$$

Specific leaf area (SLA) is the relation between leaf area (FA) and leaf dry weight (LDW).

$$
S L A=F A / D W L
$$

Leaf weight ratio (LWR) represents the relation between the mass of leaf dry weight (LDW) and total dry weight (TDW).

$$
L W R=L D W / T D W
$$

\subsection{Extraction and Analysis of Steviol Glycosides (SGs)}

The extraction and analysis of SGs was performed in the Laboratory of Pharmaceutical Technology of the University of Southern Santa Catarina (UNISUL) by HPLC according to methodology developed by Kolb et al. (2001). Leaf samples $(1 \mathrm{~g})$ were dried in a hot air oven at $65 \pm 2{ }^{\circ} \mathrm{C}$ until constant weight was achieved and ground. Steviol glycoside were extracted with $70 \%$ ethanol at $70{ }^{\circ} \mathrm{C}$ for 30 minutes on a shaker and then filtered. The obtained extract was dissolved in $5 \mathrm{ml} \mathrm{HPLC}$-grade Acetonitrile-water (8:2) mobile phase. Aliquots (20 uL) of extract were loaded onto a HPLC Shimadzu ${ }^{\circledR}$ (SPD-10A), column $\mathrm{NH}_{2}(250 \times 4.6 \mathrm{~mm})$, operated at the following conditions: isocratic Elution. 80:20 (v/v) acetonitrile/water ( $\mathrm{pH} 5.0)$, flow rate $2 \mathrm{~mL} \mathrm{~m}^{-1}$; wavelength of UV detector, $210 \mathrm{~nm}$, sensitivity adjusted to 0.04 AUFS. The compounds in each sample were identified and quantified by comparing their retention times with those of standards. The calibration curve was obtained with standards of Ste (98\% purity) and Reb-A (96\% purity) obtained from Sigma Aldrich.

\subsection{Statistical Analysis}

Data were analyzed in a completely randomized design with a factorial scheme $7 \times 2$ comparing seven stevia accessions and two cuts, with five replications using the Statistica 7 software (Stat Soft Inc., Tulca, OK, USA). Least significant differences between means were calculated by Scott-Knott test $(P \leq 0.05)$.

The Principal Components Analysis (PCA) was performed on the mean values of the morphological and physiological characters and SGs variation within the accessions. A biplot analysis and its graphical output were then used to associate the stevia accessions and the observed quantitative traits. The correlation matrix was also established for the morphology characters, biomass accumulation, physiology indices and productivity of SGs.

\section{Results and Discussion}

\subsection{Morphological Characters and Biomass Accumulation}

The dry leaf yield of all stevia accessions was higher in the first cut $\left(2.8\right.$ to $\left.4.0 \mathrm{t} \mathrm{ha}^{-1}\right)$ compared to the second cut $\left(0.7\right.$ to $\left.1.3 \mathrm{t} \mathrm{ha}^{-1}\right)$. The pruning performed due to the first cut associated with the photoperiod (mean 11.4 hours) was probably related to the lower vegetative development in the second cut and consequently to the lower dry leaf yield. However, there was a significant variation in dry leaf yield among the accessions. The CE4 had the highest productivity of dry leaf yield in first cut $\left(4.3 \mathrm{t} \mathrm{ha}^{-1}\right)$ and second cut $\left(1.3 \mathrm{~kg} \mathrm{ha}^{-1}\right)$ when compared to other accessions (Table 2). It was also observed low stem yield in the second cut $\left(0.5\right.$ to $\left.1.4 \mathrm{t} \mathrm{ha}^{-1}\right)$ when compared to the first cut (5.4 to $8.3 \mathrm{t} \mathrm{ha}^{-1}$ ). In the first cut, CE4 presented the highest stem yield and in the second cut, both CE4 and CE14 were superior (Table 2).

During the experiment, the precipitation was lower than $200 \mathrm{~mm}$ in the two plant growth periods, and this fact may have influenced the results obtained. The precipitation is also a limiting factor for stevia and according to Lavini et al. (2008) precipitation below $200 \mathrm{~mm}$ impairs productivity, directly affecting the production of stevia biomass. In spite of this, dry leaf yield of accessions 4, 9 and 12 were higher than those found by Andolfi et al. (2006), Fronza and Folegatti (2003), González et al. (2007), Lima Filho et al. (2004), Megeji et al. (2005), Pal et al. $(2013,2015)$, and Serfaty et al. (2013). For the first year of cultivation whose values ranged between 1.6 and $4.4 \mathrm{tha}^{-1}$. In addition, agronomic conditions also influence the productivity of stevia biomass yield; Tadesse et al. 
(2016) obtained the maximum dry leaf yield $\left(7.8 \mathrm{tha}^{-1}\right)$ in spacing higher densities of plants. These suggest that in addition to the climatic conditions, the agronomic conditions should also be adjusted for each genotype.

No differences were found for leaf:stem ratio in the first cut and for most accessions, the second cut provided the largest leaf:stem ratio. The CE6, CE8 and CE9 accessions showed the highest leaf:stem ratio in the second cut (on average 1.34). For the other accessions the leaf:stem ratio ranged from 0.51 to 1.08 (Table 2). In stevia breeding programs high leaf:stem ratios are desirable for cultivated plants because of the low Ste concentrations $\left(<5 \mathrm{mg} \mathrm{g}^{-1}\right)$ in stem tissues (Brandle and Rosa, 1992; Singh and Rao, 2005).

The number of secondary branches (NSB) per plant varied from 20 (CE7) to 71 (CE9) in the first cut and from 14 (CE14) to 50 (CE4) in the second cut. CE9 and CE4 accessions in the first (71 branches per plant) and second cut (50 branches per plant), respectively. The number of tertiary branches (NTB) in first cut was significantly higher compared to the second cut. CE14 and CE9 produced more tertiary branches in the first cut CE8 and CE9 in the second. CE9 was the only stevia acess with the highest NTB in the first and second cuts (Table 2).

The higher plant development and SGs content and yield observed for all accessions in the first cut compared to the second were probably related with the environmental conditions (precipitation, solar radiation and photoperiod) in the field experiment. In addition, the cutting of stevia plants during short-day periods induces flowering as soon as the plant reaches the appropriate physiological age, even with lower plant growth (Lima Filho et al., 2004). Stevia is a short-day plant with a critical photoperiod between 12 to 13 hours day length and at this conditions the glycosides accumulation increase (Madan et al., 2010; Midmore \& Rank, 2002; Valio \& Rocha, 1977). During the second plant growth period, photoperiod was below 12 hours, which may have reduced the plant growth and SGs content and yield as mentioned by Ceunen and Geuns (2013) where increase in leaf biomass and the content of SGs are usually found in long day conditions.

The CE7 and CE14 accessions showed the highest plant heights in the first cut and also the highest percentage of lodging, being $93 \%$ and $96 \%$ for CE7 and CE14 respectively. CE9 was the only access that did not present lodging in the first cut. The plant height was also significantly lower $(0.31$ to $0.48 \mathrm{~m})$ in the second cut for all accessions and consequently the lodging percentage was reduced (Table 2).

Table 2. Dry leaf $\left(\mathrm{t} \mathrm{ha}^{-1}\right)$ and dry stem yield $\left(\mathrm{t} \mathrm{ha}^{-1}\right)$, leaf:stem ratio, number of secondary (NSB) and tertiary branches (NTB), height (m) and lodging (\%) of seven stevia accessions at two harvests stages (Curitiba, PR, Brazil)

\begin{tabular}{|c|c|c|c|c|c|c|c|c|c|c|c|c|c|c|}
\hline \multirow{2}{*}{ Access } & \multicolumn{2}{|c|}{$\begin{array}{l}\text { Dry leaf yield } \\
\qquad\left(\mathrm{t} \mathrm{ha}^{-1}\right)\end{array}$} & \multicolumn{2}{|c|}{$\begin{array}{c}\text { Dry stem yield } \\
\left(\mathrm{t} \mathrm{ha}^{-1}\right)\end{array}$} & \multicolumn{2}{|c|}{$\begin{array}{l}\text { Leaf:stem } \\
\text { ratio }\end{array}$} & \multicolumn{2}{|c|}{$\begin{array}{c}\begin{array}{c}\text { NSB } \\
\text { (number) }\end{array} \\
\text { Cutting Stage }\end{array}$} & \multicolumn{2}{|c|}{$\begin{array}{c}\text { NTB } \\
\text { (number) }\end{array}$} & \multicolumn{2}{|c|}{$\begin{array}{l}\text { Height } \\
\text { (m) }\end{array}$} & \multicolumn{2}{|c|}{$\begin{array}{c}\text { Lodging } \\
(\%)\end{array}$} \\
\hline & $1^{\mathrm{st}}$ & $2^{\text {nd }}$ & $1^{\mathrm{st}}$ & $2^{\text {nd }}$ & $1^{\text {st }}$ & $2^{\text {nd }}$ & $1^{\mathrm{st}}$ & $2^{\text {nd }}$ & $1^{\text {st }}$ & $2^{\text {nd }}$ & $1^{\mathrm{st}}$ & $2^{\text {nd }}$ & $1^{\mathrm{st}}$ & $2^{\text {nd }}$ \\
\hline CE4 & $4.3 \mathrm{Aa}$ & $1.3 \mathrm{Ab}$ & $8.3 \mathrm{Aa}$ & $1.3 \mathrm{Ab}$ & $0.51 \mathrm{Ab}$ & $0.98 \mathrm{Ca}$ & $34 \mathrm{Cb}$ & $50 \mathrm{Aa}$ & $337 \mathrm{Ba}$ & $150 \mathrm{Bb}$ & $0.90 \mathrm{Ba}$ & $0.43 \mathrm{Ab}$ & $11 \mathrm{Ca}$ & $\mathrm{OBb}$ \\
\hline CE6 & 3.1Da & $0.8 \mathrm{Cb}$ & $6.7 \mathrm{Da}$ & $0.5 \mathrm{Cb}$ & $0.49 \mathrm{Ab}$ & $1.35 \mathrm{Aa}$ & $35 \mathrm{Cb}$ & $43 \mathrm{Ba}$ & $261 \mathrm{Ca}$ & $98 \mathrm{Cb}$ & $0.76 \mathrm{Ca}$ & $0.32 \mathrm{Cb}$ & $22 \mathrm{Ba}$ & $0 \mathrm{Bb}$ \\
\hline CE7 & $3.2 \mathrm{Da}$ & $0.8 \mathrm{Cb}$ & $5.4 \mathrm{Fa}$ & $0.9 \mathrm{Bb}$ & $0.60 \mathrm{Ab}$ & $0.89 \mathrm{Ca}$ & $20 \mathrm{Ea}$ & $12 \mathrm{~Eb}$ & 109Da & $69 \mathrm{Ca}$ & $1.11 \mathrm{Aa}$ & $0.46 \mathrm{Ab}$ & $93 \mathrm{Aa}$ & $4 \mathrm{Ab}$ \\
\hline CE8 & $2.8 \mathrm{Fa}$ & $0.8 \mathrm{Cb}$ & $5.6 \mathrm{Fa}$ & $0.5 \mathrm{Cb}$ & $0.50 \mathrm{Ab}$ & $1.34 \mathrm{Aa}$ & $32 \mathrm{Ca}$ & $22 \mathrm{Db}$ & $360 \mathrm{Ba}$ & $55 \mathrm{Cb}$ & $0.69 \mathrm{Da}$ & $0.36 \mathrm{Bb}$ & $9 \mathrm{Ca}$ & $0 \mathrm{Bb}$ \\
\hline CE9 & $4.0 \mathrm{Ba}$ & $0.7 \mathrm{Db}$ & 7.9Ba & $0.5 \mathrm{Cb}$ & $0.51 \mathrm{Ab}$ & $1.33 \mathrm{Aa}$ & $71 \mathrm{Aa}$ & $30 \mathrm{Cb}$ & $1,399 \mathrm{Aa}$ & $209 \mathrm{Ab}$ & $0.70 \mathrm{Da}$ & $0.31 \mathrm{Cb}$ & 0Da & $0 \mathrm{Ba}$ \\
\hline CE12 & $3.7 \mathrm{Ca}$ & $1.0 \mathrm{Bb}$ & $7.4 \mathrm{Ca}$ & $1.0 \mathrm{Bb}$ & $0.50 \mathrm{Ab}$ & $1.08 \mathrm{Ba}$ & $46 \mathrm{Ba}$ & $23 \mathrm{Db}$ & $341 \mathrm{Ba}$ & $70 \mathrm{Cb}$ & $0.91 \mathrm{Ba}$ & $0.38 \mathrm{Bb}$ & $11 \mathrm{Ca}$ & $\mathrm{OBb}$ \\
\hline CE14 & $3.1 \mathrm{Ea}$ & $0.7 \mathrm{Db}$ & $6.4 \mathrm{Ea}$ & $1.4 \mathrm{Ab}$ & $0.48 \mathrm{Aa}$ & $0.51 \mathrm{Da}$ & $25 \mathrm{Da}$ & $14 \mathrm{~Eb}$ & $133 \mathrm{Da}$ & $70 \mathrm{Cb}$ & $1.16 \mathrm{Aa}$ & $0.48 \mathrm{Ab}$ & $96 \mathrm{Aa}$ & $4 \mathrm{Ab}$ \\
\hline $\mathrm{CV}(\%)$ & 3.58 & & 5.10 & & 9.15 & & 10.37 & & 14.67 & & 6.71 & & 10.37 & \\
\hline
\end{tabular}

Note. Means followed by same capital letter in the column and small letter in the row are not statistically different according to Scott-Knott test $(\mathrm{P}<0.05) .1^{\text {st }}=$ first. $2^{\text {nd }}=$ second. $\mathrm{CV}=$ coefficient of variation.

\subsection{Physiological Indices}

LAI was higher in the first cut in all accessions, which shows the greater plant growth compared with the second cut. CE9 presented higher LAI in the first cut (7.0), but in the second cut it was the lowest (1.1). However, accessions CE7, CE8 and CE14 presented lower LAI in the first and second cuts.

For the majority of accessions the highest SLA was obtained in the second cut, only the CE4 access presented a lower SLA in the second cut $\left(12.0 \mathrm{~m}^{2} \mathrm{~kg}^{-1}\right)$ in relation to the first cut $\left(14.2 \mathrm{~m}^{2} \mathrm{~kg}^{-1}\right)$. This may be due to the 
reduced leaf area in the second cut, since larger leaf area results in greater leaf shading and consequently lower radiation incidence. In the first cut SLA ranged from $17.4 \mathrm{~m}^{2} \mathrm{~kg}^{-1}$ (access CE9) and $10.8 \mathrm{~m}^{2} \mathrm{~kg}^{-1}$ (access CE7).

LAR increased in the second cut. The accessions CE6, CE8, CE9 and CE12 were the ones with the highest LAR $\left(10.1,9.7,9.4\right.$ and $9.8 \mathrm{~m}^{2} \mathrm{~kg}^{-1}$, respectively) in the second cut. The CE14 access presented lower LAR values in the first and second cuts (4.1 and $5.2 \mathrm{~m}^{2} \mathrm{~kg}^{-1}$, respectively).

For most accessions, the LWR was high in the second cut. The CE14 access showed the lowest LWR (0.34) and with no statistical difference in the first cut (0.33). The accessions CE6 (0.60), CE8 (0.58) and CE9 (0.57) presented the highest LWR in the second cut.

Table 3. Physiology indices of the seven stevia accessions (Curitiba, PR, Brazil)

\begin{tabular}{|c|c|c|c|c|c|c|c|c|}
\hline \multirow{2}{*}{ Access } & \multicolumn{2}{|c|}{ LAI } & \multicolumn{2}{|c|}{$\operatorname{SLA}\left(\mathrm{m}^{2} \mathrm{~kg}^{-1}\right)$} & \multicolumn{2}{|c|}{$\operatorname{LAR}\left(\mathrm{m}^{2} \mathrm{~kg}^{-1}\right)$} & \multicolumn{2}{|c|}{ LWR } \\
\hline & $1^{\text {st }}$ cut & $2^{\text {nd }}$ cut & $1^{\text {st }}$ cut & $2^{\text {nd }}$ cut & $1^{\text {st }}$ cut & $2^{\text {nd }}$ cut & $1^{\text {st }}$ cut & $2^{\text {nd }}$ cut \\
\hline CE4 & $6.0 \mathrm{Ba}$ & $1.6 \mathrm{Bb}$ & $14.2 \mathrm{Ca}$ & $12.0 \mathrm{Db}$ & $4.8 \mathrm{Bb}$ & $6.1 \mathrm{Ca}$ & $0.34 \mathrm{Ab}$ & $0.51 \mathrm{Ba}$ \\
\hline CE6 & $5.0 \mathrm{Ca}$ & $1.3 \mathrm{Cb}$ & $15.3 \mathrm{Bb}$ & $16.8 \mathrm{Ba}$ & $5.0 \mathrm{Ab}$ & 10.1 Aa & $0.33 \mathrm{Ab}$ & $0.60 \mathrm{Aa}$ \\
\hline CE7 & $3.5 \mathrm{Ea}$ & $1.3 \mathrm{Cb}$ & $10.8 \mathrm{~Eb}$ & $15.1 \mathrm{Ca}$ & 4.1 Bb & 7.1 Ba & $0.38 \mathrm{Ab}$ & $0.47 \mathrm{Ca}$ \\
\hline CE8 & $3.8 \mathrm{Da}$ & $1.3 \mathrm{Cb}$ & $13.6 \mathrm{Cb}$ & $16.6 \mathrm{Ba}$ & $4.5 \mathrm{Bb}$ & $9.7 \mathrm{Aa}$ & $0.33 \mathrm{Ab}$ & $0.58 \mathrm{Aa}$ \\
\hline CE9 & 7.0 Aa & $1.1 \mathrm{Cb}$ & $17.4 \mathrm{Aa}$ & $16.4 \mathrm{Ba}$ & $5.9 \mathrm{Ab}$ & $9.4 \mathrm{Aa}$ & $0.34 \mathrm{Ab}$ & $0.57 \mathrm{Aa}$ \\
\hline CE12 & $6.1 \mathrm{Ba}$ & $2.0 \mathrm{Ab}$ & $16.2 \mathrm{Bb}$ & $18.9 \mathrm{Aa}$ & $5.4 \mathrm{Ab}$ & $9.8 \mathrm{Aa}$ & $0.33 \mathrm{Ab}$ & $0.52 \mathrm{Ba}$ \\
\hline CE14 & $3.9 \mathrm{Da}$ & $1.1 \mathrm{Cb}$ & $12.6 \mathrm{Db}$ & $15.6 \mathrm{Ca}$ & $4.1 \mathrm{Bb}$ & $5.2 \mathrm{Da}$ & $0.33 \mathrm{Aa}$ & $0.34 \mathrm{Da}$ \\
\hline CV $(\%)$ & 8.21 & & 5.52 & & 10.62 & & 6.67 & \\
\hline
\end{tabular}

Note. Means followed by same capital letter in the column and small letter in the row are not statistically different according to Scott-Knott test $(\mathrm{P}<0.05) .1^{\text {st }}=$ first. $2^{\text {nd }}=$ second. $\mathrm{LAI}=$ leaf area index. SLA $=$ specific area. $\mathrm{LAR}=$ leaf area ratio. $\mathrm{LWR}=$ leaf weight ratio. $\mathrm{CV}=$ coefficient of variation.

\subsection{Steviol Glycosides}

The content of Ste and Reb-A was significantly higher in the first cut for all accessions, ranging from $11.0 \%$ to $16.6 \%$. In the second cut, the percentage of Ste varied from $6.8 \%$ to $12.9 \%$. CE4 access presented the highest percentage of Ste in the first (16.6\%) and in the second (12.9\%) cut, but with no difference to CE7 (12.4\%) and CE12 (11.8\%) in the second cut (Table 4).

The productivity of Ste was higher for all accessions in the first cut $\left(355 \mathrm{~kg} \mathrm{ha}^{-1}\right.$ to $\left.700 \mathrm{~kg} \mathrm{ha}^{-1}\right)$ compared to the second cut $\left(44 \mathrm{~kg} \mathrm{ha}^{-1}\right.$ to $\left.177 \mathrm{~kg} \mathrm{ha}^{-1}\right)$. CE4 presented the highest productivity of Ste in both cuts (Table 4).

Reb-A (\%) various from 14\% (CE7) to $2.4 \%$ (CE14) in the first cut, and from 9.1\% (CE7) to $1.8 \%$ (CE12) in the second cut. Low Reb-A contents were observed in the CE12 and CE4 accessions, and the highest was observed in the CE14 and CE7 accessions in first and second cuts. In the first cut, it were observed Reb-A:Ste ratio greater than 1.0 in CE7 and CE14 accessions (1.01 and 1.08, respectively). The Reb-A:Ste ratio for CE4, CE6, CE9 and CE12 accessions was not statistically different (Table 4).

The cultivation cycle and stevia harvesting regime affects leaf biomass production and SGs (Pal et al., 2015). In the climatic conditions of southern Brazil, where the experiment was carried out, there was a need to advance the second harvest due to the accumulations of SGs from its peak at the beginning of flowering, which is the ideal time to harvest the leaves in terms of quality (Bondarev et al., 2003). This fact benefits the production of stevia by generating a surplus. 
Table 4. Content and productivity of the Stevioside (Ste) and Rebaudioside-A (Reb-A) and Reb-A:Ste ratio of seven accessions Stevia rebaudiana (Curitiba, PR, Brazil)

\begin{tabular}{|c|c|c|c|c|c|c|c|c|c|c|}
\hline \multirow{2}{*}{ Access } & \multicolumn{2}{|c|}{ Ste $(\%)$} & \multicolumn{2}{|c|}{ Reb-A (\%) } & \multicolumn{2}{|c|}{ Ste $\left(\mathrm{kg} \mathrm{ha}^{-1}\right)$} & \multicolumn{2}{|c|}{ Reb-A (kg ha $\left.{ }^{-1}\right)$} & \multicolumn{2}{|c|}{ Reb-A:Ste ratio } \\
\hline & $1^{\text {st }}$ cut & $2^{\text {nd }}$ cut & $1^{\text {st }}$ cut & $2^{\text {nd }}$ cut & $1^{\text {st }}$ cut & $2^{\text {nd }}$ cut & $1^{\text {st }} \mathrm{cut}$ & $2^{\text {nd }}$ cut & $1^{\text {st }}$ cut & $2^{\text {nd }}$ cut \\
\hline CE4 & $16.6 \mathrm{Aa}$ & $12.9 \mathrm{Ab}$ & $3.1 \mathrm{Ea}$ & $2.1 \mathrm{~Eb}$ & $700 \mathrm{Aa}$ & $177 \mathrm{Ab}$ & $129 \mathrm{Fa}$ & $28 \mathrm{Db}$ & $0.19 \mathrm{Da}$ & $0.16 \mathrm{Ea}$ \\
\hline CE6 & $11.0 \mathrm{Ea}$ & $6.8 \mathrm{Db}$ & $10.4 \mathrm{Ba}$ & $6.3 \mathrm{Bb}$ & $355 \mathrm{Ga}$ & $49 \mathrm{Db}$ & $340 \mathrm{Ca}$ & $45 \mathrm{Cb}$ & $0.95 \mathrm{Ba}$ & $0.92 \mathrm{Aa}$ \\
\hline CE7 & $13.9 \mathrm{Ba}$ & $12.4 \mathrm{Ab}$ & $14.0 \mathrm{Aa}$ & $9.1 \mathrm{Ab}$ & $456 \mathrm{Da}$ & $103 \mathrm{Bb}$ & $457 \mathrm{Aa}$ & $76 \mathrm{Ab}$ & $1.01 \mathrm{Aa}$ & $0.73 \mathrm{Bb}$ \\
\hline CE8 & $14.9 \mathrm{Ba}$ & $8.0 \mathrm{Cb}$ & $7.4 \mathrm{Ca}$ & $5.3 \mathrm{Cb}$ & $423 \mathrm{Ea}$ & $65 \mathrm{Cb}$ & $210 \mathrm{Ea}$ & $42 \mathrm{Cb}$ & $0.50 \mathrm{Cb}$ & $0.66 \mathrm{Ca}$ \\
\hline CE9 & $12.0 \mathrm{Da}$ & $6.8 \mathrm{Db}$ & $6.0 \mathrm{Da}$ & $3.2 \mathrm{Db}$ & $483 \mathrm{Ca}$ & $44 \mathrm{Db}$ & $237 \mathrm{Da}$ & $21 \mathrm{Db}$ & $0.50 \mathrm{Ca}$ & $0.47 \mathrm{Da}$ \\
\hline CE12 & $14.2 \mathrm{Ba}$ & $11.8 \mathrm{Ab}$ & $2.4 \mathrm{Fa}$ & $1.8 \mathrm{~Eb}$ & $527 \mathrm{Ba}$ & $166 \mathrm{Bb}$ & $89 \mathrm{Ga}$ & $18 \mathrm{Db}$ & $0.17 \mathrm{Da}$ & $0.16 \mathrm{Ea}$ \\
\hline CE14 & $12.8 \mathrm{Ca}$ & $10.2 \mathrm{Bb}$ & $13.9 \mathrm{Aa}$ & $8.7 \mathrm{Ab}$ & $395 \mathrm{Fa}$ & $74 \mathrm{Cb}$ & $427 \mathrm{Ba}$ & $63 \mathrm{Bb}$ & $1.08 \mathrm{Aa}$ & $0.86 \mathrm{Ab}$ \\
\hline CV (\%) & 4.28 & & 3.70 & & 4.24 & & 3.77 & & 6.95 & \\
\hline
\end{tabular}

Note. Means followed by same capital letter in the column and small letter in the row are not statistically different according to Scott-Knott test $(\mathrm{P}<0.05) .1^{\text {st }}=$ first. $2^{\text {nd }}=$ second. $\mathrm{CV}=$ coefficient of variation.

\subsection{Correlation Matrix and Principal Component Analysis (PCA)}

A correlation matrix of 16 quantitative traits was analyzed using Pearson correlation coefficient (Table 5). Dry leaf $\left(\mathrm{t} \mathrm{ha}^{-1}\right)$ and dry stem yields $\left(\mathrm{t} \mathrm{ha}^{-1}\right)$ were positively correlated with LAI $(0.96)$ (Table 5$)$. Ste $\left(\mathrm{kg} \mathrm{ha}^{-1}\right)$ and Reb-A yield $\left(\mathrm{kg} \mathrm{ha}^{-1}\right)$ was positively correlated with dry leaf yield $\left(\mathrm{t} \mathrm{ha}^{-1}\right)$ and stem yield $\left(\mathrm{t} \mathrm{ha}^{-1}\right)$. On the other hand, negative correlation was found between leaf:stem ratio and height, dry leaf yield, dry stem yield and SGs. In this study, the higher biomass production in the first cut compared to the second one was positively correlated with SGs content and productivity in all stevia accessions. The accessions CE4 and CE12 were the ones with the highest leaf dry mass and Ste yield as observed by Ceunen and Geuns (2013) and Pal et al. (2015). On the other hand, CE7 and CE14 showed a high positive correlation between height and productivity of Reb-A. In this case, lodging which is an undesired characteristic (Wu \& Ma, 2016) was also positively correlated with height. Both accessions produced in the first cut a total of $457 \mathrm{~kg} \mathrm{ha}^{-1}$ and $427 \mathrm{~kg} \mathrm{ha}^{-1}$ of Reb-A, respectively, which was superior of what was found by Parris et al. ( 2016) are larger than the average Reb-A ( $\left.300 \mathrm{~kg} \mathrm{ha}^{-1}\right)$ found in different stevia cultivars grown in regions of Western United States. In the region of the Rio Grande do Sul State, in Southern Brazil the maximum Reb-A was $175.7 \mathrm{~kg} \mathrm{ha}^{-1}$ (Pereira et al., 2016).

Plant height was the morphological character that presented a high positive correlation with the SG yield, which also had a positive and significant correlation $(\mathrm{P}<0.05)$ with dry leaf yield. The number of branches had no significant correlation with SGs content and productivity.

SGs were negatively correlated with physiology indices as LAR, SLA and LWR and positively correlated with LAI (Table 5). The maximum leaf production was a result of high LAI, which enhanced light interception capacity. The LWR represents the fraction of mass not exported to other parts of the plant, which may be related to the low production of SGs in the second cut maybe due the reduced redirection of photoassimilates.

There was also a positive correlation ( 0.82 ) between Reb-A content and productivity (Table 5), which suggests that the selection of stevia genetic material with high productivity will provide great content of Reb-A. 
Table 5. Pearson correlation matrix for stevia characters (Curitiba, PR, Brazil)

\begin{tabular}{|c|c|c|c|c|c|c|c|c|c|c|c|c|c|c|c|c|}
\hline Variable & $\begin{array}{l}\text { Ste } \\
(\%)\end{array}$ & $\begin{array}{l}\text { Reb-A } \\
(\%)\end{array}$ & $\mathrm{R}: \mathrm{S}$ & LAI & DLY & DSY & $\mathrm{L}: \mathrm{S}$ & NBS & NBT & Height & LAR & SLA & LWR & Lodging & $\begin{array}{l}\text { Ste } \\
\left(\mathrm{kg} \mathrm{ha}^{-1}\right)\end{array}$ & $\begin{array}{l}\text { Reb-A } \\
\left(\mathrm{kg} \mathrm{ha}^{-1}\right)\end{array}$ \\
\hline Ste (\%) & 1 & & & & & & & & & & & & & & & \\
\hline Reb-A (\%) & $n s$ & 1 & & & & & & & & & & & & & & \\
\hline $\mathrm{R}: \mathrm{S}$ & $n s$ & $0.90^{* *}$ & 1 & & & & & & & & & & & & & \\
\hline LAI & $0.62^{*}$ & $n s$ & $n s$ & 1 & & & & & & & & & & & & \\
\hline DLY & $0.72^{* *}$ & $n s$ & $n s$ & $0.96^{* *}$ & 1 & & & & & & & & & & & \\
\hline DSY & $0.70^{* *}$ & $n s$ & $n s$ & $0.96^{* *}$ & $0.98^{* *}$ & 1 & & & & & & & & & & \\
\hline $\mathrm{L}: \mathrm{S}$ & $-0.75^{* *}$ & $n s$ & $n s$ & $-0.73^{* *}$ & $-0.78^{* *}$ & $-0.83^{* *}$ & 1 & & & & & & & & & \\
\hline NBS & $n s$ & $n s$ & $n s$ & $0.57^{*}$ & $n s$ & $n s$ & $n s$ & 1 & & & & & & & & \\
\hline NBT & $n s$ & $n s$ & $n s$ & $0.70^{* *}$ & $0.57^{*}$ & $0.56^{*}$ & $n s$ & $0.78^{* *}$ & 1 & & & & & & & \\
\hline Height & $0.69^{* *}$ & $0.55^{*}$ & $n s$ & $0.70^{* *}$ & $0.84^{* *}$ & $0.84^{* *}$ & $-0.79^{* *}$ & $n s$ & $n s$ & 1 & & & & & & \\
\hline LAR & $-0.76^{* *}$ & $n s$ & $n s$ & $-0.60^{*}$ & $-0.73^{* *}$ & $-0.76^{* *}$ & $0.93^{* *}$ & $n s$ & $n s$ & $-0.82^{* *}$ & 1 & & & & & \\
\hline SLA & $n s$ & $n s$ & $n s$ & $n s$ & $n s$ & $n s$ & $n s$ & $n s$ & $n s$ & $-0.58^{*}$ & $0.69^{* *}$ & 1 & & & & \\
\hline LWR & $-0.72^{* *}$ & $n s$ & $n s$ & $-0.74^{* *}$ & $-0.79^{* *}$ & $-0.85^{* *}$ & $0.99^{* *}$ & $n s$ & $n s$ & $-0.78^{* *}$ & $0.91^{* *}$ & $n s$ & 1 & & & \\
\hline Lodging & $n s$ & $0.76^{*}$ & $n s$ & $n s$ & $n s$ & $n s$ & $n s$ & $n s$ & $n s$ & $0.82^{*}$ & $n s$ & $-0.84^{* *}$ & $n s$ & 1 & & \\
\hline Ste $\left(\mathrm{kg} \mathrm{ha}^{-1}\right)$ & $0.82^{* *}$ & $n s$ & $n s$ & $0.92^{* *}$ & $0.97^{* *}$ & $0.95^{* *}$ & $-0.77^{* *}$ & $n s$ & $n s$ & $0.83^{* *}$ & $-0.72^{* *}$ & $n s$ & $-0.77^{* *}$ & $n s$ & 1 & \\
\hline Reb-A $\left(\mathrm{kg} \mathrm{ha}^{-1}\right)$ & $n s$ & $0.82^{* *}$ & $0.59^{*}$ & $n s$ & $0.65^{*}$ & $0.65^{*}$ & $-0.63^{*}$ & $n s$ & $n s$ & $0.84^{* *}$ & $-0.70^{* *}$ & $-0.58^{*}$ & $-0.63^{*}$ & $0.89^{* *}$ & $0.55^{*}$ & 1 \\
\hline
\end{tabular}

Note. Dry leaf yield - DLY $\left(\mathrm{t} \mathrm{ha}^{-1}\right)$; dry stem yield - DSY $\left(\mathrm{t} \mathrm{ha}^{-1}\right)$; number of secondary branches - NSB; number of tertiary branches - NTB; leaf area index - LAI; specific leaf area - SLA; leaf area ratio - LAR; leaf weight ratio - LWR. ${ }^{* *} P \leq 0.01$ represent significant values; ${ }^{*} P \leq 0.05 ; n s$ not significant.

Principal component analysis (PCA) was carried out using morphology and physiology parameters and SGs in the first and second cuts (Figures 1 and 2).

The first principal component of the first cut accounted for $57.39 \%$ of the total variation and Reb-A (\%) contributed more to the variation (0.30), followed by lodging (\%) (0.29), Reb-A $\left(\mathrm{kg} \mathrm{ha}^{-1}\right)(0.28)$, Reb-A:Ste ratio $(0.27)$ and height $(0.22)$. All others characters contributed negatively to the first component. Second principal component contributed $19.53 \%$ of the total variation which had Ste (\%) (0.52), Ste $\left(\mathrm{kg} \mathrm{ha}^{-1}\right)(0.46)$, leaf:stem ratio (0.24), RPF (0.23), DLY (0.22) and height (0.22) as main sources of variation.

For the first cut, according to their dispersion on the PCA diagram, the accessions were distinctly separated (Figure 1B). CE7 and CE14 were closely related ad it presented higher lodging (\%), Reb-A (\%), Reb-A (kg ha $\left.{ }^{-1}\right)$ and height $(\mathrm{m})$. CE4 was separated from the other accessions mainly because of the higher Ste content and productivity. The accessions CE6 and CE8 were distinguished from the CE4 access by the lower percentage of Ste and lower productivity of Ste. CE4 presented a high dry leaf yield and it had a high positive correlation with the productivity of Ste (Table 5). CE9 access was characterized by the higher values of LAI, LAR and SLA. 
A

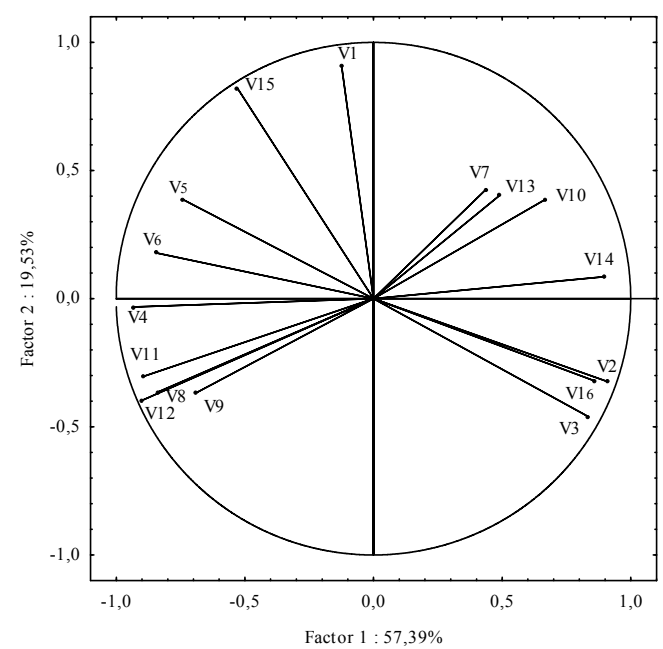

B

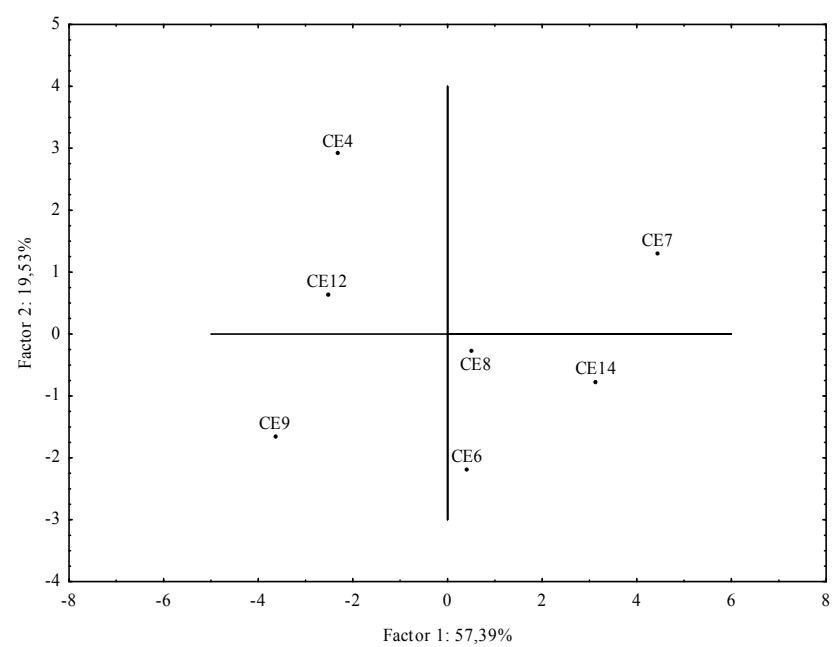

Figure 1. Biplot of principal components based on mean value of percentage of Ste in dry leaf $\left(\mathrm{V}_{1}\right)$, percentage Reb-A in dry leaf $\left(\mathrm{V}_{2}\right)$, Reb-A:Ste ratio $\left(\mathrm{V}_{3}\right)$, LAI $\left(\mathrm{V}_{4}\right)$, dry leaf yield $\left(\mathrm{V}_{5}\right)$, dry stem yield $\left(\mathrm{V}_{6}\right)$, leaf:stem ratio $\left(\mathrm{V}_{7}\right)$, NSB $\left(\mathrm{V}_{8}\right)$, NTB $\left(\mathrm{V}_{9}\right)$, height $(\mathrm{cm})\left(\mathrm{V}_{10}\right)$, LAR $\left(\mathrm{V}_{11}\right)$, SLA $\left(\mathrm{V}_{12}\right)$, LWR $\left(\mathrm{V}_{13}\right)$, lodging $\left(\mathrm{V}_{14}\right)$, Ste $\left(\mathrm{kg} \mathrm{ha}^{-1}\right)$

$\left(\mathrm{V}_{15}\right)$ and Reb-A $\left(\mathrm{kg} \mathrm{ha}^{-1}\right)\left(\mathrm{V}_{16}\right)$ in the first cut of the seven stevia accessions $(\mathrm{A})$ and $(\mathrm{B})$ Variable vector distributions and case distributions (accessions), respectively. The loading values of variables are presented (A) as vectors in the space of the PCA biplots (Curitiba, PR, Brazil)

The first principal component of the second cut accounted for $44.44 \%$ of the total variation and plant height contributed more to this variation (0.36), followed by lodging (0.34), DSY $\left(\mathrm{t} \mathrm{ha}^{-1}\right)(0.30)$, Reb-A $\left(\mathrm{kg} \mathrm{ha}^{-1}\right)(0.29)$, Reb-A (\%) (0.25) and Ste (\%) (0.23). Second principal component contributed 33.68\% of the total variation. And Reb-A:Ste (0.38), Reb-A (\%) (0.30) and Reb-A $\left(\mathrm{kg} \mathrm{ha}^{-1}\right)(0.22)$ were the mani souces of this variation.

The PCA biplot for the second cut showed that CE7 and CE14 are more related by the larger lodging (\%), height (m), Reb-A (\%) and Reb-A ( $\left.\mathrm{kg} \mathrm{ha}^{-1}\right)$. CE4 and CE12 accessions are characterized in the second cut by the largest LAI, DLY, Ste (\%)and Ste $\left(\mathrm{kg} \mathrm{ha}^{-1}\right)$. The CE6, CE8 and CE9 accessions are more related by the largest leaf:stem ratio, LAR $\left(\mathrm{m}^{2} \mathrm{~kg}^{-1}\right)$ and LWR and smaller Ste $\left(\mathrm{kg} \mathrm{ha}^{-1}\right)$ and dry leaf yield $\left(\mathrm{tha}^{-1}\right)$ (Figures 2A and $\left.2 \mathrm{~B}\right)$. 
A

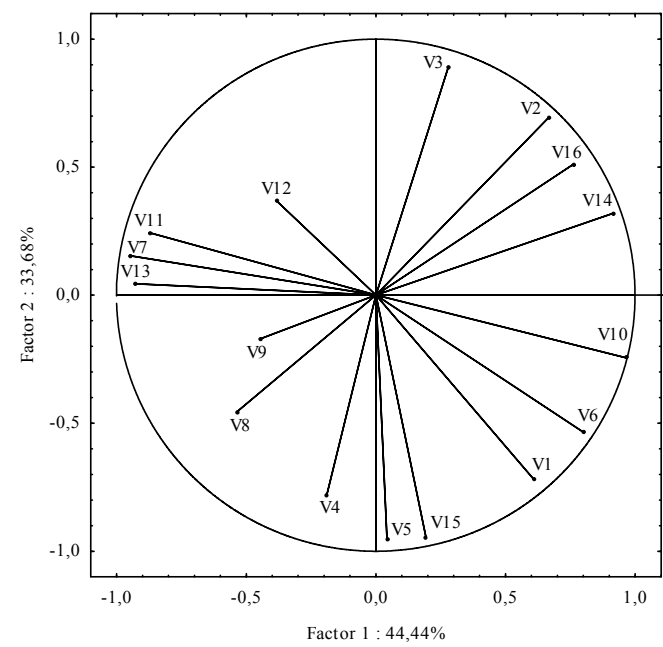

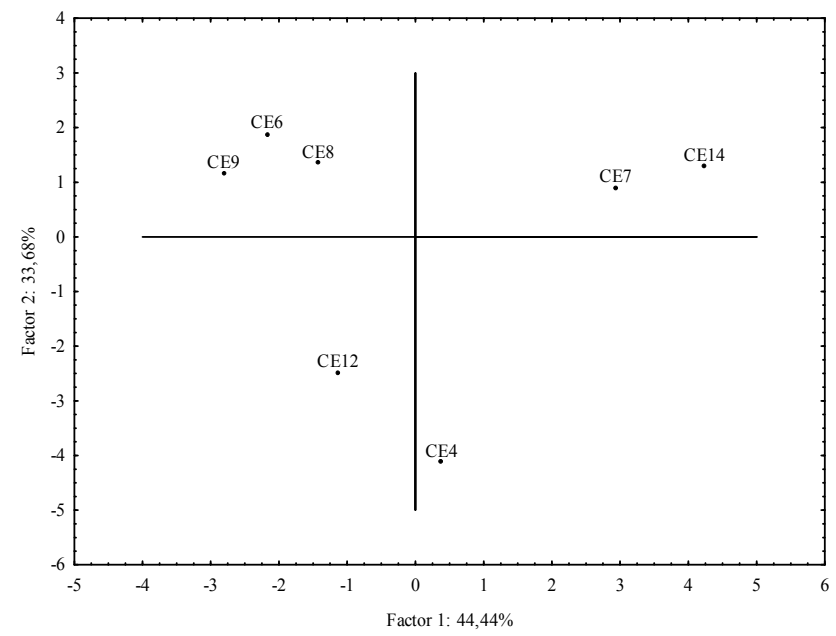

Figure 2. Biplot of principal components based on mean value of percentage of Ste in dry leaf $\left(\mathrm{V}_{1}\right)$, percentage Reb-A in dry leaf $\left(\mathrm{V}_{2}\right)$, Reb-A:Ste ratio $\left(\mathrm{V}_{3}\right)$, LAI $\left(\mathrm{V}_{4}\right)$, dry leaf yield $\left(\mathrm{V}_{5}\right)$, dry stem yield $\left(\mathrm{V}_{6}\right)$, leaf:stem ratio $\left(\mathrm{V}_{7}\right)$, NSB $\left(\mathrm{V}_{8}\right)$, NTB $\left(\mathrm{V}_{9}\right)$, height $(\mathrm{cm})\left(\mathrm{V}_{10}\right)$, LAR $\left(\mathrm{V}_{11}\right)$, SLA $\left(\mathrm{V}_{12}\right)$, LWR $\left(\mathrm{V}_{13}\right)$, lodging $\left(\mathrm{V}_{14}\right)$, Ste $\left(\mathrm{kg} \mathrm{ha}^{-1}\right)$ $\left(\mathrm{V}_{15}\right)$ and Reb-A $\left(\mathrm{kg} \mathrm{ha}^{-1}\right)\left(\mathrm{V}_{16}\right)$ in the second cut of the seven stevia accessions. (A) and (B) Variable vector distributions and case distributions (accessions), respectively. The loading values of variables are presented (A) as vectors in the space of the PCA biplots (Curitiba, PR, Brazil)

The overall PCA analysis in both cuts indicates that the accessions CE7 and CE14 are characterized by increased Reb-A yield, height and lodging (\%). CE4 and CE12 presented high Ste and dry leaf yield and the accessions CE6, CE8 and CE9 the highest leaf:stem ratio and low SGs.

The accessions CE7 and CE14 that presented high Reb-A:Ste ratio which are most desired by industry as Reb-A has the best profile relative to all others glycosides and is more soluble in water (Ahmed \& Dobberstein, 1982; Crammer \& Ikan, 1986; Huang et al., 1995). So, the main objective of the stevia breeding programs is to develop new varieties with high levels of Reb-A (Dacome et al., 2005; Sekaran et al., 2007). In southern Brazil, previously work demonstrated that Reb-A:Ste ratio obtained for cultivar UEM-320 ranged between 1.05 and 1.15 (Dacome et al., 2005), this together with the results found in the present study suggest that it is possible to grow stevia and obtain quality raw material for the industry in the southern region on the country.

\section{Conclusions}

The evaluated stevia accessions have characteristics of the interest for crop improvement, both in terms of biomass and SGs production under recommended climatic conditions for the cultivation. Accessions CE7 and CE14 presented the best results for the production of Reb-A, the main characteristic of interest in stevia breeding programs.

\section{References}

Ahmed, M. S., \& Dobberstein, R. H. (1982). Stevia rebaudiana II. High performance liquid chromatographic separation and quantitation of stevioside, rebaudioside A and rebaudioside C. Journal Chromatografy, 236(2), 523-526.

Anami, E. T., Vidigal, M. C. G., Vidigal Filho, P. S., Lacanallo, G. F., Gonela, A., \& Poletine, J. P. (2010). Characterization and genetic divergence in Stevia rebaudiana (Bert.) Bertoni clones based in agronomical and morphological characteristics. International Journal of Food, Agriculture and Environment, 8(3/4), $1-18$.

Andolfi, L., Macchia, M., \& Ceccarini, L. (2006). Agronomic-productive characteristics of two genotype of Stevia rebaudiana in Central Italy. Italian Journal of Agronomy, 1(2), 257-262. https://doi.org/10.4081/ ija.2006.257

Bondarev, N. I., Sukhanova, M. A., Reshetnyak, O. V., \& Nosov, A. M. (2003). Steviol glycoside content in different organs of Stevia rebaudiana and its dynamics during ontogeny. Biologia Plantarum, 47(2), 261-264. https://doi.org/10.1023/B:BIOP.0000022261.35259.4f 
Brandle, J. E., \& Rosa, N. (1992). Heritability for yield, leaf: stem ratio and stevioside contente estimated from a landrace cultivar of Stevia rebaudiana. Canadian Journal Plant Science, 72(4), 1263-1266. https://doi.org/ 10.4141/cjps92-159

Ceunen, S., \& Geuns, J. M. C. (2013). Influence of photoperiodism on the spatio-temporal accumulation of steviol glycosides in Stevia rebaudiana (Bertoni). Plant Science, 198, 72-82. https://doi.org/10.1016/ j.plantsci.2012.10.003

Crammer, B., \& Ikan, R. (1986). Sweet glycosides from the stevia plant. Chemistry in Britain, 22(10), 915-916.

Dacome, S., da Silva, C. C., da Costa, C. E. M., Fontana, J. D., Adelmann, J., \& da Costa, S. C. (2005). Sweet diterpenic glycosides balance of a new cultivarof Stevia rebaudiana (Bert) Bertoni: isolation and quantitative distribution by chromatographic, spectroscopic and electrophoretic methods. Process Biochemistry, 44(11), 3587-3594. https://doi.org/10.1016/j.procbio.2005.03.035

Fronza, D., \& Folegatti, M. V. (2003). Water consumption of the stevia (Stevia rebaudiana (Bert.) Bertoni) crop estimated through microlysimeter. Scientia. Agricola, 60(3), 595-599. https://doi.org/10.1590/S0103-9016 2003000300028

Giraldo, C., Marín, L., \& Habeych, D. (2005). Obtención de Edulcorantes de Stevia rebaudiana Bertoni. Revista CENIC Ciências Biológicas, 36, 3-10.

González, H. R., Luz, A., Sosa, I. H., Amita, M. M. R., Ferradá, C. A. R., Govín, E. S., \& Figueredo, M. M. (2007). Comportamiento del cultivo de Stevia rebaudiana (Bertoni) Bertoni em Cuba. Revista Cubana de Plantas Medicinales, 12(4), 121-124.

Huang, Y. S., Guo, A. G., Qian, Y., Chen, L. Y., \& Gu, H. F. (1995). Studies on the variation of steviosides content and selection of type R-A in Stevia rebaudiana. Journal of Plant Research Environmental, 4, $28-32$.

Industry ARC. (2014). Global stevia/Stevia rebaudiana market (2013-2018)? By types (liquid and powdered); by application (dairy, bakery, canned food, beverages and others) and by geography. Retrieved from http://industryarc.com/Domain/2/agriculture-market-research.html

Kinghorn, A. D. (2002). Stevia: The genus Stevia. CRC Press: New York. https://doi.org/10.4324/9780203165942

Kolb, N., Herrera, J. L., Ferreyra, D. J., \& Uliana, R. F. (2001). Analysis of sweet diterpene glycosides from Stevia rebaudiana: improved HPLC method. Journal of Agricultural and Food Chemistry, 49(10), 4538-4541. https://doi.org/10.1021/jf010475p

Lavini, A., Riccardi, M., Pulvento, C., Luca, S., Scamosci, M., \& d'Andria, R. (2008). Yield, quality and water consuption of Stevia rebaudiana Bertoni grown under diferente irrigation regimes in Southern Italy. Italian Journal of Agronomy, 3(2), 135-143. https://doi.org/10.4081/ija.2008.135

Lima Filho, O. F., Valois, A. C. C., \& Lucas, Z. M. (2004). Sistemas de produção: Estévia. Dourados, MS: Embrapa Agropecuária Oeste.

Madan, S., Ahmad, S., Singh, G. N., Kohli, K., Kumar, Y., Singh, R., \& Garg, M. (2010). Stevia rebaudiana (Bert.) Bertoni: A revew. Indian Journal of Natural Products and Resources, 1(3), 267-286.

Megeji, N. W., Kumar, J. K., Singh, V., Kaul, V. K., \& Ahuja, P. S. (2005). Introducing Stevia rebaudiana, a natural zero-calorie sweetener. Current Science, 88(5), 801-804.

Midmore, D. J., \& Rank, A. H. (2002). A new rural industry stevia to replace imported chemical sweeteners (RIRDC Publication No. W02/22).

Mondança, R. L., Gálvez, A. V., Bravo, L. Z., \& Hen, K. A. (2012). Stevia rebaudiana Bertoni, source of a high-potency natural sweetener: A comprehensive review on the biochemical, nutritional and functional aspects. Food Chemistry, 132(3), 1121-1132. https://doi.org/10.1016/j.foodchem.2011.11.140

Murashige, T., \& Skoog, F. A. (1962). A revised medium for a rapid growth and bioassays with tobacco tissues cultures. Plant Physiology, 15, 473-479. https://doi.org/10.1111/j.1399-3054.1962.tb08052.x

Pal, P. K., Prasad, R., \& Pathania, V. (2013). Effect of decapitation and nutrient applications on shoot branching, yield, and accumulation of secondary metabolites in leaves of Stevia rebaudiana Bertoni. Journal Plant Physiology, 15(17), 1526-1535. https://doi.org/10.1016/j.jplph.2013.06.017

Pal, P. K., Mahajan, M., Prasad, R., Pathania, V., Singh, B., \& Ahuja, P. S. (2015). Harvesting regimes to optimize yield and quality in annual and perennial Stevia rebaudiana under sub-temperate conditions. Industrial Crops \& Products, 65, 556-564. https://doi.org/10.1016/j.indcrop.2014.09.060 
Parris, C. A., Shock, C. C., \& Qian, M. (2016). Dry leaf and steviol glycoside productivity of Stevia rebaudiana in the Western United States. HortScience, 51, 1220-1227. https://doi.org/10.21273/HORTSCI11149-16

Pereira, C., Storck, L., Lopes, S. J., Martin, T. N., \& Bisognin, D. A. (2016). Dry biomass and glycosides yield from Stevia rebaudiana leaves under different harvesting times. Bioscience Journal, 32(6), 1462-1471. https://doi.org/10.14393/BJ-v32n6a2016-31574

Radford, P. S. (1967). Growth analysis formulae: Their use and abuse. Crop Science, 7(3), 171-175. https://doi.org/10.2135/cropsci1967.0011183X000700030001x

Ramesh, K. Singh, V., \& Megeji, W. (2006). Cultivation of stevia (Stevia rebaudiana (Bert.) Bertoni): A comprehensive review. Advances in Agronomy, 89, 137-177. https://doi.org/10.1016/S0065-2113(05) 89003-0

Rieck, U. W. (2012). The leaves of Stevia rebaudiana (Bertoni), their constituents and the analyses thereof: A review. Journal of Agricultural and Food Chemistry, 60(4), 886-895. https://doi.org/10.1021/jf2044907

ROLAS. (2004). Manual de adubação e calagem para os estados do Rio Grande do Sul e Santa Catarina (p. 394). Porto Alegre: Sociedade Brasileira de/ciências do Solo, Núcleo Regional Sul.

Saad, A., Khan, F. A., Hayee, A., \& Nazir, M. S. (2014). A review on potential toxicity of artificial sweetners vs safety of stevia: a natural bio-sweetner. Journal of Biology, Agriculture and Healthcare, 4(15).

Sekaran, T., Giridhar, P., Ravishankar, G. A. (2007). Production of steviosides in ex vitro and in vitro grown Stevia rebaudiana Bertoni. Journal of the Science of Food and Agriculture, 87(3), 420-424. https://doi.org/ $10.1002 /$ jsfa. 2713

Serfaty, M., Ibdah, M., Fischer, R., Chaimovitsh, D., Saranga, Y., \& Dudai, N. (2013). Dynamics of yield components and stevioside production in Stevia rebaudiana grown under different planting times, plant stands and harvest regime. Industrial Crops \& Products, 50, 731-736. https://doi.org/10.1016/ j.indcrop.2013.08.063

Singh, S. D., \& Rao, G. P. (2005). Stevia: The herbal sugar of the $21^{\text {st }}$ century. Sugar Technology, 7(1), 17-24. https://doi.org/10.1007/bf02942413

Tadesse, N., Gebere, A., Lulie, B., \& Hordofa, M. (2016). Influence of plant population density on growth and yield of stevia (Stevia rebaudiana Bertoni L.) at Wondo Genet south Ethiopia. Academic Research Journal of Agricultural Science and Research, 4(6), 321-329. https://doi.org/10.14662/ARJASR2016.038

Valio, I. F. M., \& Rocha, R. F. (1977). Effect of photoperiod and growth regulators on growth and flowering of Stevia rebaudiana Bertoni. Japanese Journal of Crop Science, 46(2), 243-248. https://doi.org/10.1626/ jcs. 46.243

Wu, W., \& Ma, B. L. (2016). A new method for assessing plant lodging and the impact of management options on lodging in canola crop production. Scientific Reports, 6, 1-17. https://doi.org/10.1038/srep31890

Yadav, A. K., Dhyani, S. D., \& Ahuja, P. S. (2011). A review on the improvement of stevia [Stevia rebaudiana (Bertoni)]. Canadian Journal of Plant Science, 91, 1-27. https://doi.org/10.4141/CJPS10086

\section{Copyrights}

Copyright for this article is retained by the author(s), with first publication rights granted to the journal.

This is an open-access article distributed under the terms and conditions of the Creative Commons Attribution license (http://creativecommons.org/licenses/by/4.0/). 